Martha Chamallas*

\title{
The Elephant in the Room: Sidestepping the Affirmative Consent Debate in the Restatement (Third) of Intentional Torts to Persons
}

\author{
https://doi.org/10.1515/jtl-2017-0025
}

Abstract: In contemporary debates about legal responsibility for sexual misconduct, the status of "affomative consent" is front and center. Most often associated with the campus rape crisis and the enforcement of Title IX by colleges and universities, affirmative consent places responsibility on individuals who initiate sex to secure the affirmative permission of their partners before engaging in sexual conduct. Going beyond "no means no," affirmative consent is best captured by the slogan "only yes means yes" and aims to protect those sexual assault victims who react passively or silently in the face of sexual aggression, even though they do not desire to have sex and would not have initiated the sexual activity if they had been given the choice. The criminal law in most states has not yet caught up with these developments and has continued to require either a showing of "force" on the part of the defendant or proof of a verbal objection on the part of the victim.

Given its prominence, one might expect affirmative consent to emerge as a central issue in the revision of the Restatement (Third)'s provisions on consent. Instead, affirmative consent makes an appearance only briefly in the Restatement's commentary and has not affected the core black letter statements of the law of consent. Although purporting to be neutral, the approach of the Restatement (Third) is incompatible with affirmative consent, both in the Restatement's definitions of actual and apparent consent and in its determination to assign the burden of proof to the plaintiff instead of the defendant. Because there is no controlling precedent that would prevent the Restatement (Third) from embracing affirmative consent, the Restatement (Third) is free to follow the Title IX model and incorporate affirmative consent into the body of tort law. This article makes the case for adopting affirmative consent in sexual misconduct tort cases, even if the criminal law in any given jurisdiction continues to apply a more defendant-oriented consent rules.

*Corresponding author: Martha Chamallas, Moritz College of Law, Ohio State University, Columbus, Ohio, USA, E-mail: chamallas.1@osu.edu 
Keywords: affirmative consent, civil rights, apparent consent, intentional torts to person, sexual assault

In contemporary debates about legal responsibility for sexual misconduct, the status of "affirmative consent" is front and center. Most often associated with the campus rape crisis and enforcement of Title IX by colleges and universities, affirmative consent places responsibility on individuals who initiate sex to secure the affirmative permission or consent of their partners before engaging in sexual conduct. In popular parlance, affirmative consent goes beyond the mandate that "no means no" and is often connected to the slogan "only yes means yes." Although the concept has been around for decades, ${ }^{1}$ it has only recently gained traction as a legal strategy to bolster sexual autonomy, especially for women.

The affirmative consent movement shines a spotlight on the crucial role "consent" has played and continues to play in demarcating lawful from unlawful sexual conduct, in both the criminal and civil law. It has been vigorously debated (and at this point rejected) in the current effort to revise the Model Penal Code $^{2}$ and was the centerpiece of the Obama-era overhaul of Title IX standards for college disciplinary actions, ${ }^{3}$ now likely in jeopardy with the change of administration. Aside from the scorecard of victories and defeats for affirmative consent, however, it seems clear that the perennial struggle over legal limits on sexual misconduct will continue to center on the definition, application, and meaning of consent. Although many feminists - most prominently Catharine MacKinnon $^{4}$ - would prefer to jettison consent as the touchstone of legality and concentrate on refurbishing the meaning of "coercion" to determine what constitutes rape and sexual assault, a newer generation of feminists has embraced what Deborah Turkheimer calls "the culture of consent" and seem intent on

1 Antioch College was the first educational institution to adopt an affirmative consent policy in 1991, requiring that "if one person wants to initiate moving to a higher level of sexual intimacy in an interaction, that person is responsible for getting the verbal consent of the other person(s) involved.” See Phil McCombs, Taking a Look at Love, WASH. Post, 16th February 1996, at F5. For early academic advocacy of affirmative consent, see Martha Chamallas, Consent, Equality and the Legal Control of Sexual Conduct, 61 So. CAL. L. REV. 777, 836 (1988) (advocating mutuality model of sexual relationships); Lois Pineau, Date Rape: A Feminist Analysis, 8 LAw \& PHIL. 217, 233-237 (1989) (advocating model of communicative sexuality); Stephen J. Schulhofer, Taking Sexual Autonomy Seriously, 11 LAW \& PHIL. 35, 74 (1992).

2 See infra at n. 38.

3 See infra at nn. 61-63.

4 Catharine A. MacKinnon, Towards A Feminist Theory of the State 175 (1989). 
reclaiming consent and making it a focal point for social mobilization and change. ${ }^{5}$

Given the swirl of activity around affirmative consent, one might expect it to emerge as a central issue in the revision of the Restatement (Third)'s provisions on consent. ${ }^{6}$ However, affirmative consent makes an appearance only briefly in the commentary to the new provisions and has not affected the core black letter statements of the law of consent. On the surface, the Restatement (Third) purports to take the position that states are free to adopt affirmative consent in cases of sexual battery and to send a neutral signal on whether taking such a step would be advisable. However, just below the surface, the signal from the Restatement is decidedly more mixed. By retaining the traditional definitions of both actual consent ${ }^{7}$ and apparent consent, ${ }^{8}$ the Restatement reinforces a consent regime that is incompatible with acceptance of affirmative consent. Additionally, by choosing to assign the plaintiff the burden of proving her lack of consent, ${ }^{9}$ the Restatement (Third) compounds the difficulty of incorporating affirmative consent into the body of tort law.

As a preliminary matter, I should note that my comments on the consent provisions in the Restatement (Third) are quite limited in scope. My sole focus is on intentional tort claims arising from sexual conduct, even though the Restatement covers the full range of consent cases, many of which, of course, have nothing to do with sexual conduct. Additionally, in this essay, I do not discuss the Restatement's provision on incapacity, duress and substantial mistake (§15) that determines those exceptional instances in which a person's consent is deemed ineffective. ${ }^{10}$ Instead, my analysis is directed at the core meanings of consent, the basic threshold determination in intentional tort cases.

Despite its limited scope, the topic of consent in sexual conduct cases is important and complicated. Sexual conduct cases are a distinctive subset of consent cases that repeatedly surface in the Reporters' comments, notes and illustrations. Together with medical consent cases and claims arising in the context of athletics and sports, they comprise the bulk of the discussion on consent in the Restatement (Third) and deserve scrutiny in their own right.

5 Deborah Tuerkheimer, Rape on and off Campus, 65 EMORY L.J. 1, 8 (2015).

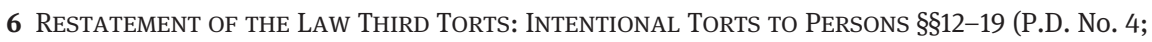
6th March 2017) [hereinafter RESTATEMENT (THIRD) or RESTATEMENT].

7 See infra at n. 66.

8 See infra at n. 73.

9 See infra at n. 82.

$10 \mathrm{My}$ analysis also does not cover other Restatement provisions on consent that address specific issues, i. e., scope of consent (§14), implied-in-law consent (§17), emergency doctrine (§18), inadequate consent to medical treatment as battery (§19). 
It also bears mentioning that, even with respect to this limited topic, it is very difficult to do justice in a short essay to an effort as sophisticated and complex as the Restatement (Third). Although my comments are largely critical and will suggest that the Restatement has not gone far enough to protect the sexual autonomy of plaintiffs, in many respects, the document is quite progressive and is a far cry from earlier Restatements that seemed oblivious and even antagonistic to the interests of women and other victims of sexual violence and exploitation. There is much in the Third Restatement for feminists to admire. For this essay, however, I have decided to defer the praise and cut right to the chase.

This essay begins with a description of affirmative consent, noting its key features and pointing out some of the ambiguities and the difficulties lawmakers encounter in trying to operationalize the concept. ${ }^{11}$ I then attempt to distill the voluminous literature on consent to present the most compelling rationales and arguments for adopting some version of affirmative consent. ${ }^{12}$ To do so, it is necessary to spend some time recounting the ignominious history of criminal rape laws because the criminal law continues to dominate the broader cultural debate on consent. ${ }^{13}$ Before moving to torts and the Restatement, the essay briefly discusses consent-related developments in two major civil rights statutes, Title VII (governing discrimination in employment) and Title IX (governing discrimination in education), that form the backdrop for analysis of consent in the civil litigation context. ${ }^{14}$

The rest of the essay is devoted to describing the approach of the Restatement (Third) and explaining how that approach is incompatible with a concept of affirmative consent. ${ }^{15}$ I make the argument that the Restatement (Third) could embrace affirmative consent without deviating from its Restatement mission and that it should do so. ${ }^{16}$ Finally, I suggest that the Restatement (Third) adopt a separate provision embracing affirmative consent in sexual conduct cases. ${ }^{17}$ As a second-best option, I would prefer that the Restatement take no position on whether its general provisions on actual consent, apparent consent and burden of proof apply to sexual conduct cases, unambiguously clearing the way for states to adopt affirmative consent in such cases. ${ }^{18}$

\footnotetext{
11 See infra at nn. 19-25.

12 See infra at nn. 26-55.

13 See infra at nn. 26-33.

14 See infra at nn. 56-65.

15 See infra at nn. 66-94.

16 See infra at nn. 95-109.

17 See infra at n. 110.

18 Id.
} 


\section{The meaning of affirmative consent}

As with any evolving concept, there are many variations of affirmative consent, as the non-uniform wording of disciplinary codes in colleges and universities across the country will attest, For our purposes, however, the essential features of the concept are captured by the definition of affirmative consent found in California legislation that requires all higher education institutions in that state to incorporate affirmative consent definitions into their disciplinary codes. That legislation provides:

\footnotetext{
"Affirmative consent" means affirmative, conscious, and voluntary agreement to engage in sexual activity. It is the responsibility of each person involved in the sexual activity to ensure that he or she has the affirmative consent of the other or others to engage in the sexual activity. Lack of protest or resistance does not mean consent, nor does silence mean consent. Affirmative consent must be ongoing throughout a sexual activity and can be revoked at any time. The existence of a dating relationship between the persons involved, or the fact of past sexual relations between them, should never by itself be assumed to be an indicator of consent. ${ }^{19}$
}

The California definition of affirmative consent has four key features. First and foremost, it imposes a responsibility or duty on the actor or initiator of sexual activity to ensure that his or her partner has affirmatively consented to sex. Second, it clarifies that silence or a lack of protest or resistance on the victim's part - victim responses that are sometimes regarded as ambiguous or even probative of consent in the context of sexual conduct - do not qualify as affirmative consent. Third, it conceptualizes sexual activity as comprising different acts or stages. Rather than focusing solely on penetration as the defining stage of sexual activity, it requires that consent be ongoing and capable of being revoked at any time. Finally, it prohibits reliance on the fact that the parties had a dating relationship or had prior sexual relations as a reason for presuming that sexual activity between them was consensual.

Although the affirmative consent statute states that each of the parties has a responsibility, building in a mutual duty, it is important to note that when actual disputes over consent arise, frequently the allegation will be that one party (most often, but not invariably, a man) was the initiator or aggressor and failed to secure the consent of the other party (most often, but not invariably, a woman). Despite its gender neutral and mutual duty terminology, the definition of affirmative consent tracks a recurring problem in rape and sexual assault

19 CAL. Educ. Code $§ 67,386$ (West 2015). 
cases, namely, whether consent was secured from the party who did not initiate the activity.

The rest of the statute tends to flesh out the meaning of "affirmative" in affirmative consent, in both a positive and a negative sense. On the positive side, it highlights that the person consenting must be "conscious," ruling out the possibility that a sleeping or unconscious party could consent. It also describes the requisite consent as constituting a "voluntary agreement," emphasizing the exercise of free will on the part of each party. Lastly, it describes the requisite consent in active, dynamic terms, characterizing it as ongoing and capable of disappearing through revocation. On the negative side, it contrasts "affirmative" consent with submission or acquiescence. This is accomplished by specifying that consent cannot be presumed from passive responses from a victim, such as silence, the failure to protest or resist, or the simple fact of a relationship between the parties, absent current indication of the party's agreement to have sex on the particular occasion.

While the definition of affirmative consent in the California statute is quite detailed, it is not invariably tied to a particular theoretical or philosophical orientation and is better understood as a pragmatic attempt to repudiate earlier, less protective definitions of consent, particularly in the criminal law, which I will discuss shortly. For now, it is enough to point out that it is possible to fit affirmative consent within both a "mental state" and a "performative" account of $_{\text {consent. }}{ }^{20}$

The mental state account of consent focuses on the private, subjective attitude of the party giving consent, while the performative account of consent focuses on the consenting party's public manifestation or behavior. In the mental state account of affirmative consent, a key inquiry is often described as whether the consenting party "desired" the sexual contact, even if such desire was not communicated to the other party. In the performative account, consent is an act that one does, rather than an existing mental state, i. e., the act of giving permission to another to do something that would otherwise not be allowed. Under the performative account, desire and consent are not always linked because it is possible to desire something, yet refuse to give consent (e. g., a person may want or desire to have sex with another, but nevertheless refuses her permission because she is in an exclusive relationship with someone else). Likewise, it possible to give one's consent to have sex, even though desire

20 For a fuller discussions of the difference between a "mental state" and a "performative" account of consent, see JOAN MCGREGOR, Is IT RAPE? ON ACQUAINTANCE RAPE AND TAKING Women's Consent Seriously 116-135 (2005); Alan Wertheimer, Consent to SeXual RELATIONS 145-147 (2003). 
is lacking (e.g., a person consents to have sex with a long-term partner in order to sustain the relationship).

Some theorists of affirmative consent have stated that the concept of affirmative consent fits best with a performative account of consent, mainly because this account of affirmative consent makes it more difficult to infer consent in ambiguous, contested circumstances. ${ }^{21}$ However, affirmative consent standards, such as that found in the California legislation, can also be interpreted consistently with a mental state account of consent. Because it is often impossible to secure first-hand evidence of a party's mental state, the California statute can be read to provide mandatory standards for determining when there is sufficient evidence of a party's desires or wishes to warrant a finding of consent. Whether the display (or performance) of consent operates as direct proof of affirmative consent or is simply evidence of the requisite mental state associated with affirmative consent is likely to remain an unanswered question. While it would be helpful in particular cases to know whether the law of consent is aimed at a mental state or a performative act, it is not essential to subscribe to one or the other account to choose whether to endorse the basic concept of affirmative consent.

Understanding the basic contours of affirmative consent, of course, is not the same as reaching a consensus on how to identify affirmative consent in a given context. Admittedly, like so many fundamental concepts in tort law think, negligence, reasonableness, and causation - affirmative consent is somewhat ambiguous and open-ended. For example, Professor Aya Gruber a trenchant critic of affirmative consent - has developed an affirmative consent scale to describe different formulations of affirmative consent that she discerns in various university disciplinary codes. ${ }^{22}$ On Gruber's scale, a more regulatory (I might call it a "more protective") formulation of affirmative consent either requires a verbal "yes" from the person consenting, or its behavioral equivalent, putting the obligation on the initiator to "stop, seek, and obtain permission" before proceeding to engage in a specific sexual act (e. g., moving from touching or kissing to intercourse). ${ }^{23}$ According to Gruber, a less regulatory formulation of affirmative consent (short of specifying a duty to "stop and ask") requires the person giving consent to convey her consent through "words and/or conduct that clearly and contemporaneously convey agreement."24

21 See MCGREGOR, supra note 20 at 125; WERTHEIMER, supra note 20 at 145-147.

22 Aya Gruber, Consent Confusion, 38 CARDozo L. REV. 415, 431-432 (2016).

23 Id. at 432-433.

24 Id. at 436. 
In contrast to these formulations of affirmative consent, Gruber describes two other formulations of consent ("contextual consent" and "no means no") that do not qualify as affirmative consent, although to some degree they are more protective than traditional criminal law definitions of consent. ${ }^{25}$ Under contextual consent, the victim's words and conduct (including silence and omissions) are scrutinized to determine whether "in context" they convey agreement. Contextual consent fundamentally differs from the affirmative consent approaches just mentioned in that, under contextual consent, factfinders are given free rein to interpret silence, inaction and pre-existing relationships as consent and are permitted to find consent in cases in which passive victims offer no verbal or other resistance. Finally, some criminal laws require a finding of consent unless the victim expresses her objection to the defendant's action, making consent turn on the presence or absence of a verbal objection or refusal. While these laws respect that "no means no," they too allow factfinders to infer consent from silence and inaction and they presume consent (rather than a lack of consent) from a victim's passive response.

This essay borrows Gruber's demarcation line to separate affirmative consent formulations from other approaches. The important point here is that the Restatement (Third) does not endorse any of the various formulations of affirmative consent she identifies, opting instead for a less protective approach that resembles contextual consent.

Before looking more closely at the law as it relates to affirmative consent, it is important to recognize that the movement toward affirmative consent is more than just a push for specific legal reforms. By revising the very concept that defines sexual violation, a newer generation of (mostly) women is also seeking to influence and change cultural norms. Affirmative consent is a thus a way to name and call out oppressive and sexist behaviors (the negative, dangerous side of sex), while simultaneously claiming the right of every person to be treated as an active, sexual being (the positive, pleasurable side of sex). This dual focus on the negative and positive sets the affirmative consent movement apart from earlier struggles that focused mainly on the danger of sexual conduct and curbing the most severe forms of sexual abuse. In this respect, the goal of affirmative consent is more connected to sexual freedom and autonomy.

25 Id. at 438. 


\section{The rationale for affirmative consent}

The concept of affirmative consent cannot be fully understood without appreciating the history of the law of consent as it has played out in the criminal law. Affirmative consent is a responsive concept - it responds to (and rejects) thinner, defendant-oriented versions of consent and offers in its place a more robust, victim or plaintiff-oriented version of consent. Traditionally, consent did not play an exclusive starring role in the criminal law of rape because rape laws required not only "nonconsent" on the part of the victim but also proof of "force" exercised by the defendant. ${ }^{26}$ The independent force requirement meant that much nonconsensual sex (accomplished by means other than force) was not criminalized. Moreover, the definition of "force" used by most jurisdictions was exceedingly narrow, requiring a finding of overpowering physical force or threat of physical force. Even though penetration of a nonwilling victim would intuitively seem to require application of force, most states held that the intrinsic force used to accomplish penetration did not qualify as sufficient force under the law. Instead, the criminal law generally focused on whether the defendant had used external physical force, such as hitting, punching or otherwise battering the victim. Notably, the force requirement meant that even victims who voiced their clear verbal objection to having sex were not regarded as having been raped if the defendant was able to accomplish the act without beating or threatening the victim with physical harm. ${ }^{27}$

Traditionally, proof of non-consent under criminal rape laws also required the victim to prove that she had physically resisted defendant's actions. ${ }^{28}$ The notion here was that any woman who did not desire sex would offer physical resistance, equating passivity with consent. Originally, states required women to prove that they had resisted "to the utmost." Later, the requirement was relaxed to require only "reasonable" physical resistance. In this respect, the physical resistance requirement served to reinforce the force requirement because only if a victim physically resisted would a defendant then need to apply overpowering physical force to accomplish the act. Another reason that women who verbally

26 See Martha Chamallas, Introduction to Feminist Legal Theory 290-294 (3d ed. 2012) (discussing changing criminal law definitions of rape).

27 A notorious case requiring extrinsic force which helped to catalyze the "no means no" movement was Commonwealth v. Berkowitz, 641 A. 2d 1161 (Pa. 1994).

28 See Michelle J. Anderson, All-American Rape Law, 79 ST. JohN’S L. REV. 625, 628 (2005); Leigh Bienen, Rape III-National Developments in Rape Reform Legislation, 6 WOMEN'S RTS. L. RPTR. 170, 181-184 (1980). 
objected, but did not physically resist, were deemed to have consented stemmed from a widespread cultural belief about "normal" (hetero)sexual practices i. e., the belief that women were likely to offer "token resistance," even when they secretly desired to have sex. ${ }^{29}$

The traditional criminal law regime was ill-designed to protect the sexual autonomy of women, to put it mildly. Together with a host of other legal rules that applied only to rape prosecutions- the corroboration rule, the fresh complaint rule, the cautionary jury instruction, and the introduction of the victim's sexual history - the force and non-consent requirements made it very difficult to secure rape convictions. Indeed, the regime was so under-protective that some feminist critics argued that the point of rape law was to protect male sexual access to women, rather than to protect women against sexual aggression. ${ }^{30}$ Particularly when one considers that traditional rape laws did not criminalize even forcible rape of a woman committed by her husband, ${ }^{31}$ the sexual access hypothesis makes sense.

It is also important to mention how the race of the defendant and the race of the victim factored into the equation. Scholars have long been aware that judges and juries applied the elements of rape far less strictly in cases involving African American defendants and white victims, going so far in some cases as to presume that white women would not consent to having sexual intercourse with black men. ${ }^{32}$ In cases in which African American women were victims of rape, moreover, invidious presumptions about the natural promiscuity of minority women often came into play, creating a strong presumption of consent. Piecing together these disparate strands of legal doctrine and racially linked presumptions, many theorists have viewed rape law as functioning to maintain racial and gender hierarchies, placing women of all races at considerable risk of sexual abuse and minority men at risk of being falsely accused of sexual misconduct and punished severely. ${ }^{33}$

29 See David P. Bryden, Redefining Rape, 3 BufF. CRIM. L. REv. 317, 388-389 (2000) (discussing studies repudiating "token resistance" belief).

30 See Catharine A. MacKinnon, Rape: On Coercion and Consent in TOWARD A Feminist THEORY OF THE STATE 171, 175 (1989).

31 See Michelle J. Anderson, Marital Immunity, Intimate Relationships, and Improper Inferences: A New Law on Sexual Offenses by Intimates, 54 Hastings L. J. 1465, 1475 (2003).

32 See Angela P. Harris, Race and Essentialism in Feminist Legal Theory, 42 STAN. L. REv. 581 (1990); Jennifer Wriggins, Rape, Racism, and the Law, 6 HARV. WOMEN'S L. J. 103 (1983).

33 See Kimberlé Crenshaw, Demarginalizing the Intersection of Race and Sex: A Black Feminist Critique of Antidiscrimination Doctrine, Feminist Theory and Antiracist Politics, 1989 U. CHI. LEGAL F. 139, 157-160 (1989). 
On an interpersonal level, the traditional regime seemed to mimic what some have called a "conquest" model of sexuality, ${ }^{34}$ in which men are regarded as potential conquerors that regularly use various aggressive tactics (physical force, threats, coercion, deception, persistent requests) to secure sex from women who sometimes resist them but sometimes just give up and give in. Under this model, very few tactics are ruled out as unlawful and it is considered natural for men to deploy them. More importantly, traditional criminal law doctrine tended to side with the conquerors, labeling aggressive tactics as mere persuasion or seduction rather than sexual assault. Famously, Catharine MacKinnon charged that the law actually tolerated a high degree of forced sex by setting the legal standards for rape and consent at the "normal level of force" used by men to secure sex. ${ }^{35}$

The successive efforts at reforming rape law have altered this picture somewhat but have not succeeded in diminishing the need to push for more thoroughgoing change. At this point, it seems safe to say that the "no means no" campaign has met with some success. Some states have dropped their force requirement (at least with respect to some degrees of sexual assault) and many no longer require plaintiffs to prove physical resistance in order to establish non-consent. Other states effectively place more weight on non-consent by holding that the force requirement is met whenever a defendant persists in penetrating a woman who has not consented, treating the intrinsic force needed to accomplish that act as sufficient proof of force. ${ }^{36}$ A few states have even adopted versions of affirmative consent to govern criminal prosecutions for sexual assault. ${ }^{37}$

In response to the variation in criminal law standards, the latest version of the Model Penal Code has taken a middle-ground approach, eliminating the force requirement for certain sexual offenses, but refusing to adopt any version of affirmative consent. ${ }^{38}$ Thus, under the new provisions of the MPC, consent is defined as “a person's willingness to engage in a specific act of sexual penetration or sexual contact." ${ }^{39}$ Adopting a contextual consent approach, the MPC

\section{MCGREGOR, supra note 20, at 96.}

35 Catharine A. MacKinnon, Toward A Feminist Theory of the State 173 (1989).

36 The leading case is State ex rel. M.T.S., 609 A2d 1266 (N.J. 1992).

37 See e. g., Wis. STATE. ANN. § 940.225 (4); VT. StAT. ANN. Tit. 13, § 3251 (3); M.T.S., 609 A2d at 1277 (permission ...must be affirmative and . . given freely).

38 Model Penal Code, Article 213.0 (3), Approved Version of Section 213.0(3) (Jan. 2017). The Comment to Article 213.0 (3) states that "[t]his provision does not adopt what is commonly called "affirmative consent," which is often understood to require an explicit word ("yes") or specific act (active cooperation) to communicate a relatively formal "agreement" to the specific sexual act."

39 Id., ARTICLE 213.0(3) (a). 
allows consent to "be inferred from behavior - both action and inaction - in the context of all the circumstances," 40 thus allowing silence and passivity to count as consent. The Code goes on to specify that "a clear verbal refusal - such as "No," "Stop," or "Don't" - establishes a lack of consent," ${ }^{41}$ thus embracing a "no means no" version of consent.

Overall, these reforms have paved the way for holding defendants criminally liable for nonconsensual intercourse, at least when victims register verbal objections. This is not an unimportant change. Respecting that "no means no" is crucially important to recognizing an individual's autonomy, for we can hardly regard a regime that allows someone to proceed in the face of a victim's objections as protective of autonomy. I do not want to overstate the rate or depth of change, however. Many states have retained a force requirement, some states still require extrinsic force, and some still require a showing of physical resistance on the part of the victim. ${ }^{42}$ To this degree, the ignominious history of criminal rape laws is not really over yet.

Aside from the reluctance of some states to endorse "no means no," there is evidence that the law has failed to cut down appreciably on the high incidence of acquaintance rape, the most common kind of rape ${ }^{43}$ and the type of sexual abuse that has fueled the contemporary affirmative consent movement on college campuses. An influential study estimated that 1 in 4 college women had experienced rape or attempted rape, a figure that, while contested, has formed the baseline for institutional and grassroots efforts addressing the problem. ${ }^{44}$ Legal and social science researchers have hypothesized that rape is facilitated by the existence of rape-prone cultures in fraternities, men's athletic

40 Id., ARTICLE 213.0(3) (b).

41 Id. ARTICLE 213.0(3) (e).

42 John F. Decker \& Peter G. Baroni, "No" Still Means "Yes": The Failure of Non-Consent Reform Movement in American Rape and Sexual Assault Law, 101 J. CRIM. L. \& CRIMINOLOGY 1081, 1102 1106 (2011).

43 Approximately $70 \%$ of rapes and sexual assaults against women are committed by a relative, friend, or an acquaintance. NATIONAL CRIME ViCTIMIZATION STUDY, Violent VictimizATION OF COLLEGE STUDENTS (1995-2002), available at http://www.ojp.usdoj.gov/bjs/ cvict_c.htm and http://www.ojp.usdoj.gov/bjs/pub/pdf/vvcs02.pdf.

44 The 1 in 4 figure was first generated in 1985 by Mary Koss in a published survey of 6,000 students at thirty-two college campuses. See Amelia Thomson-DeVeaux, A New Form of Justice for Rape Survivors, Nat'l J. (1st May 2015), http://www.nationaljournal.com/magazine/2015/ 05/ 01/ New-Form-Justice-Rape-Survivors [http:// perma.cc/ BK75-8RNR]. Subsequent surveys in 2006 by the National Institute of Justice and in 2014 by a White House Task Force showed that $19 \%$ and $23 \%$, respectively, of undergraduate women were victims of sexual assault or attempted sexual assault. Christopher P. Krebs, et al., The Campus Sexual Assault (CSA) Study, U.S. Dep’t Just. 5-1 (October 2007), http://www.ncjrs.gov/pdffiles1/nij/grants/221153/pdf 
teams and other male-dominated settings in which many individuals continue to subscribe to rape myths, including such beliefs that "women mean 'yes' when they say 'no,' that women lie about rape, that women secretly desire coercive sex, that men cannot control their natural sexual urges, and that rape by an acquaintance or without a weapon is not 'real rape." 45 In such settings, moreover, there is often considerable peer support for sexual assault, which one scholar describes as a "driving force in contributing to its occurrence."46 Outside college campuses, researchers have found, the incidence of rape and sexual assault may even be higher, fostered by gender inequality in the larger society and subcultures that devalue women and girls and commodify and objectify their sexuality. ${ }^{47}$

With the spotlight on acquaintance rape, there is now a growing appreciation for the grievous injury lack-of-consent intercourse may cause, even absent infliction of additional external injuries. Victims have described the harm as "degrading," "scary," and "excruciatingly painful" and have drawn a sharp distinction between such harm and the regret or discomfort experienced from "bad" (but consensual) sex. ${ }^{48}$ Nonconsensual sexual intercourse not only may result in post-traumatic stress disorder, but may also produce a kind of harm that goes to the core of a person's identity, shattering a victim's sense of self and changing her alignments and relationships to people in her world. ${ }^{49}$ Thus, nonconsensual sex without force can cause many of the same long-term effects as forcible nonconsensual intercourse. In this respect, sexual violations are often different and more serious than other transgressions (such as stealing property from a victim) because "[i]n sexual interactions, unlike other interactions, it is even more important that we are able to control whom we are intimate with, since sexual relationships expose us more than other relationships and thereby make us more vulnerable."50

[https://perm.cc/6QD8-RB4C]; Not Alone: The First Report of the White House Task Force To Protect Students from Sexual Assault, White House 6-8 (April 2014).

45 Deborah L. Brake, Back to Basics: Excavating the Sex Discrimination Roots of Campus Sexual Assault, 6 TENN. J. RACE, GENDER \& Social Justice 7, 32 (2017).

$46 \mathrm{Id}$.

47 See Sofi Sinozich \& Lynn Langton, U.S. Dep’t of Justice Bureau of Justice Statistics, Rape and Sexual Assault Victimization Among College-Age Females, 1995-2013, at 4 (finding that women aged eighteen to twenty-four who were not college students were 1.2 times more likely to be sexually violated than women of the same age in college).

48 Lynne Henderson, Getting to Know: Honoring Women in Law and in Fact, 2 Tex. J. Women \& Law 42, 58, 64-65 (1993); Robin L. West, Legitimating the Illegitimate: A Comment on Beyond Rape, 93 Colum. L. REV. 1442, 1448 (1993).

49 See Martha Chamallas, Lucky: The Sequel, 80 InD. L.J. 441, 468-471 (2005).

50 MCGREGOR, supra note 20, at 225. 
To be clear, establishing that there is a high level of acquaintance rape and sexual assault and that such conduct may cause serious harm does not mean that every allegation of rape or sexual assault is true or that there is little or no countervailing risk of imposing liability or blame on an innocent defendant in individual cases. As one university administrator put it, even in an era known for its "hook up" culture and destigmatizing of casual sex, some women may still falsely accuse men of sexual misconduct not only out of vindictiveness, but because they live in world where women continue to be shamed for engaging in sexual activity. We cannot be entirely sure that a charge of sexual violation is warranted and not brought to "vindicate honor, provide safety from a third party, reinforce identities of sexual innocence, protect against jealousy, or protect [the claimant] from falling from someone's grace." 51 In my view, however, the balance of risks and equities still quite clearly points toward doing more, not less, to protect against sexual abuse, making affirmative consent worthy of serious consideration, especially in the context of tort law.

I find three rationales for adopting affirmative consent most compelling. First, adoption of some version of affirmative consent is needed because many women still react passively or are silent in the face of sexual aggression, even when they do not desire to have sex and would not have initiated the sexual activity. By now, we know that there are many explanations for failing to resist or register a verbal objection to sexual activity other than tacit consent. The target may be afraid ("frozen in fear"), intimidated by the defendant's physical strength or confident demeanor, socialized not to react aggressively, but rather to cry or act in "feminine," less decisive ways. She may be socially awkward or inexperienced and ashamed to reveal her lack of sophistication and understanding of sexual matters. She may be worn down by defendant's persistent attempts and finally give in because she lacks the kind of self-esteem that would allow her to place her own wishes ahead of others. Or she may simply be conflicted, unsure of whether she wants really wants to continue. If her choice is taken away by a man who "takes the initiative" and acts without her permission, that ought to count as a legal injury, especially if the law places equal weight on the sexual autonomy of each partner. In matters of sex and intimacy, there can be little question that the law rightly prioritizes the right to deny or refuse a relationship over the desire to enter into a relationship. ${ }^{52}$

51 Joan W. Howarth, Shame Agent, 66 J. LEGAL EduC. 717, 722 (2017).

52 See Kenneth Karst, The Freedom of Intimate Association, 89 YALE J. J. 624, 637-638 (1980) ("as rape and unwanted pregnancy dramatically illustrate ... coerced intimate associations are the most repugnant of all forms of compulsory associations”). 
Second, affirmative consent is needed as a corrective to ensure that the perspective and experience of victims are taken into account and given due weight under the law. The traditional criminal law has been criticized for embracing a defendant-oriented male perspective in judging consent. For example, the resistance requirement can no longer plausibly be viewed as a standard based on how women actually responded to the threat of rape. Instead it required women to fight back in a way that men imagined that they might react to an assault. The conquest model of sexuality, although accepted as reality by some women, is a male-oriented model that serves to perpetuate and justify aggressive masculinity. It is well established that when it comes to sexual encounters, men and women often have different perspectives, with competing scripts structured predictably along gender lines. ${ }^{53}$ Social science research indicates that men tend to interpret women's behavior in a sexualized way, seeing seductiveness and sexual receptivity, while women are more likely to interpret their behavior in a non-sexual way, e. g., as being friendly, cautious, or even unreceptive. ${ }^{54}$ Particularly when the meaning of nonverbal behavior is in question, the potential for misinterpreting "cues" is great. Given the historical privileging of the male perspective, affirmative consent's insistence that men who initiate sexual activity first check to determine whether their interpretation of plaintiff's conduct is right helps to prevent rape myths from filling in the gaps when actions are ambiguous or carry different meanings. Particularly the "stop and ask" formulations of affirmative consent send a message that the law seeks to protect the sexual autonomy of both parties by building in safeguards against overreaching, willful blindness, or sincere (but harmful) mistakes.

Third, affirmative consent is needed to ensure that women's interests in bodily integrity and sexual autonomy are accorded the status they deserve, on par with other fundamental interests. Both criminal law and tort law purport to place a very high weight on these interests, equal to or above interests in property. However, in many respects, sexual conduct continues to be treated exceptionally. Traditional criminal law permitted a finding of a victim's consent in sexual conduct cases - from silence, from lack of resistance, from lack of protest - even though the law would not countenance such a finding in analogous cases involving theft of property. As Susan Estrich has argued, the

53 Kim Lane Scheppele, The Re-Vision of Rape Law, 53 U. CHI. L. REv. 1095, 1104-1105 (1987). 54 For a discussions of this "two worlds" phenomenon in the context of sexual harassment, see Barbara A. Gutek, Understanding Sexual Harassment at Work, 6 NotRe DAME J. L. ETHICS \& PuB. PoL'Y 335, 343 (1992); Elizabeth L. Schoenfelt, Allison E. Maue \& JoAnn Nelson, Reasonable Person versus Reasonable Woman: Does It Matter? 10 AM. U. J. GENDER, Soc., PoL'Y \& L. 633, 647-651 (2002). 
law does not regard a victim as consenting to robbery when the assailant pins her down, strides atop her, and steals her wallet, even if the victim fails to yell "stop." It should not be enough to say that sexual conduct is different because social norms dictate that consent is often given tacitly - through body language and other nonverbal means - when those social norms are highly contested and historically skewed against one group. Nor is sex different because consent has the potential to transform an injury into a pleasurable (or at least non-injurious) experience. This transformative property of consent is present in other contexts as well when, for example, consent transforms theft into a gift. Context may be all-important, but it is important to have a thorough, not one-sided, understanding of the context. Overall, adoption of affirmative consent would eliminate the presumption of consent that often arises in sexual conduct cases, even when there is no convincing evidence that the plaintiff gave permission to the defendant to invade the boundaries of her body.

\section{Consent and civil rights}

The movement toward affirmative consent was foreshowed by developments under the civil rights laws that embody critiques of the traditional criminal law approach to consent and provide a model for reform. Both Title VII and Title IX doctrine have been re-shaped to provide a more robust concept of consent and to jettison the baggage of the criminal law. The impetus for change under both anti-discrimination statutes was to provide greater protection for women and other victims of sexual assault and sexually abusive conduct.

The first inroad came in sexual harassment cases under Title VII. Convinced that tort law was hopelessly retrograde, Catharine MacKinnon and other feminist activists employed a strategy to provide a measure of protection to women by reconceptualizing sexual abuse as a civil rights violation. Significantly, the first sexual harassment case to reach the U.S. Supreme Court dealt with consent and rejected the criminal law version of the concept. The plaintiff in Meritor Savings Bank $v$. Vinson ${ }^{56}$ alleged that she had been coerced into having sexual intercourse with her supervisor on multiple occasions, fearing that unless she gave into his demands she would lose her job. Notably, the supervisor never used physical force or the threat of physical force to obtain plaintiff's submission.

55 SusAn Estrich, ReAl RAPE 59 (1987).

56477 U.S. 57 (1986). 
Sitting as a factfinder, the trial court in Meritor Savings Bank ruled in favor of the defendant, finding that any relationship between plaintiff and her supervisor was "voluntary" and could not qualify as harassment under Title VII. In a crucial move that paved the way for sexual harassment claims to become a staple of Title VII law, the Supreme Court rejected any notion of voluntariness or consent in the determination of what qualifies as harassment, declaring that "voluntariness" in the sense of consent is not a defense to such a claim." ${ }^{57}$ In the place of consent, the Court adopted the concept of "unwelcomeness" to determine whether sexual conduct amounted to harassment and suggested that unwelcomeness would turn, at least in part, on whether the target of the harassment "found particular advances unwelcome."58

Admittedly, Meritor Bank's adoption of an unwelcomeness standard is not the same as imposing a requirement of affirmative consent. Indeed, the Court in a later, widely criticized portion of the same case, ruled that a target's "provocative speech or dress" was "obviously relevant" to determining whether sexual advances were unwelcome, ${ }^{59}$ seeming to depart from the subjective, "mentalstate-of-the- plaintiff" connotation of term "unwelcome." However, for our purposes, what is significant is the Court's move away from traditional consent in Meritor Bank and its attempt to devise a more protective standard that acknowledges the significance of power disparities between the initiator of sexual conduct and the target. In this respect, unwelcomeness can be looked upon as a more robust version of consent, one which refuses to find consent in instances in which the plaintiff submits or accedes to undesired sex out of concern for retaining her job.

By adopting the new concept of unwelcomeness, moreover, the Court made it easier for factfinders to consider the conduct in question from the victim's perspective, asking them to imagine whether the target desired or welcomed the advances or conduct. Although the Supreme Court has never ruled that the victim's perspective is determinative in Title VII cases, ${ }^{60}$ the very recognition of the claim of sexual harassment stems from a shift in cultural awareness, i. e., from seeing sexualized conduct in the workplace as mere casual banter, teasing or flirtation to judging the same conduct as harassing, abusive or hostile. This

57 Id. at 69.

58 Id.

59 Id.

60 See Martha Chamallas, Gaining Some Perspective in Tort Law: A New Take on Third-Party Criminal Attack Cases, 14 LEWIS \& ClARK L. REV. 1351, 1367-1369 (2010) (discussing victim's perspective in Title VII cases). 
cultural shift gives weight to the target's perspective and recognizes the potential for misinterpreting silence or passivity as consent.

Importantly, when the Supreme Court recognized sexual harassment as a Title VII violation in 1986 the language of Title VII had not been amended, nor could it be said that there was a clear cultural consensus or established social norm making sexual harassment in the workplace unacceptable. Instead, given contested cultural views, the Court opted for an interpretation of Title VII that best served the purposes of Title VII, namely, promoting equal employment opportunity for women. Outside the Title VII context, Meritor Savings Bank is noteworthy for its determination that consent or acquiescence induced by the economic pressure or coercion from threatened job loss should not be regarded as effective consent, at least not in the context of civil litigation. While this narrow determination certainly has relevance for intentional torts claims, it is important not to lose sight of Meritor Bank's broader critique of consent and the potential of civil rights law to provide a model for reform of the tort doctrine of consent.

While Title VII addressed victims' responses to sexual conduct, it did not directly confront the problem of acquaintance rape outside the context of employment. Adoption of an affirmative consent standard in acquaintance rape cases did not gain momentum until the Obama-era initiative to curb sexual violence on college campuses, often marked by the "Dear Colleague" Letter issued by the Office of Civil Rights, Department of Education ("OCR") to college and universities in 2011. ${ }^{61}$ The "Dear Colleague" Letter dealt mainly with procedures for adjudicating complaints of sex abuse by college disciplinary authorities and did not directly mandate that educational institutions adopt affirmative consent standards. However, as enforcement of Title IX intensified and OCR opened sexual violence investigations against more than 120 colleges and universities, ${ }^{62}$ educational institutions rapidly adopted affirmative consent rules, resulting in more than 1400 such adoptions across the country. ${ }^{63}$ Incorporating affirmative consent into disciplinary codes was often accompanied by stepped-up educational programming, training and seminars, accelerating a culture change in the meaning of consent that had been simmering for quite some time.

61 Office of Civil Rights, Dear Colleague Letter from Assistant Secretary Russlynn Ali, U.S. Dep’t of Educ. (4th April 2011).

62 See Michelle J. Anderson, Campus Sexual Assault Adjudication and Resistance to Reform. 125 Yale L. J. 1940, 1975 (2016), citing Tyler Kingkade, 124 Colleges, 40 School Districts Under Investigation for Handling Sexual Assault, HufFInGton Post (24th July 2014).

63 Sandy Keenan, Affirmative Consent: Are Students Really Asking?, N. Y. TimEs (28th July 2015). 
An important aspect of the Title IX story is that it was spearheaded by a grassroots social movement of college women, including victims of sexual assault, who charged that acquaintance rape was widespread on their campuses and that their institutions ignored, minimized or otherwise failed to respond equitably to complaints. While the anti-rape activists of the 1970s had set their sights on the "force" requirement and on ridding the criminal law of special rules that made rape particularly difficult to prosecute, contemporary college activists turned their attention to transforming the meaning of consent as it affected sexual interactions with their peers and fixed on the civil and institutional side of law enforcement. No one knows whether the cultural changes they brought about are so deeply rooted that they will survive the powerful backlash forces currently in play, including any Trump administration pull back in Title IX enforcement. However, the Title IX affirmative consent movement has already produced good examples and definitions of affirmative consent that can serve as models for drafting Restatement provisions.

For example, in addition to the California statute, discussed previously, a New York statute mandating that college and universities in that state adopt affirmative consent defines affirmative consent as "a knowing, voluntary, and mutual decision among all participants to engage in sexual activity." ${ }^{24}$ It further specifies that "consent can be given by words or actions, as long as those words or actions create clear permission regarding willingness to engage in the sexual activity." Like the California statute, the New York law explicitly states that "[s]ilence or lack of resistance, in and of itself does not demonstrate consent" and additionally provides that "[t]he definition of consent does not vary based upon the participant's sex, sexual orientation, gender identity or gender expression."

The New York statute is somewhat different from the California statute, discussed earlier, ${ }^{65}$ in that it does not specify that affirmative consent must be ongoing and does not mention that a prior dating or sexual relationship between the parties is not in and of itself an indicator of consent. Moreover, the New York statute makes it clear that affirmative consent may be given by actions as well as words, while the California statute is silent on that point. But the two statutory formulations are fundamentally similar. They each envision affirmative consent as a mutual obligation, imposing a duty on each party to make sure that he or she has the permission of the other to engage in the sexual conduct. They each refuse to equate silence and passivity with consent. And they each recognize the

64 N.Y. Educ. LAw § 6441 (McKinney 2015).

65 See supra note 19. 
perspective of the victim or target by making consent turn on a target's words or actions, rather than solely on a defendant's or a hypothetical reasonable person's interpretation of events.

The Title IX model of affirmative consent is sufficiently developed to make it ripe for consideration under tort law. It was shaped to respond to acquaintance rape and other kinds of sexual assault by non-strangers, a common occurrence that tort law has addressed and clearly should address. Under Title IX, a finding of sexual misconduct gives rise to a civil sanction (i. e., discipline of the offending student), separate and apart from criminal law, and may result in relief to individual victims (e.g., issuance of no-contact order, accommodations with respect to class attendance, etc.). Keeping these similarities in mind, the following sections turn to the Restatement (Third) and how it handles consent in intentional tort sexual misconduct cases.

\section{Approach of the restatement}

Two key Restatement provisions defining actual consent (§13) and apparent consent (\$16) are most relevant to our discussion of affirmative consent. They contain the general standards for a finding of consent and largely retain the traditional definitions of these concepts found in earlier Restatements. Additionally, the new Restatement departs from its predecessor in providing that the burden of proof is on the plaintiff to establish the absence of actual consent. It takes no position with respect to allocation of the burden of proof in apparent consent cases. The following discussion parses the Restatement's "blackletter" provisions on consent, noting references to affirmative consent and other relevant statements in the commentary and Reporters' Notes.

\subsection{Actual consent}

Section 13 defining actual consent states that "[a] person actually consents to an actor's otherwise tortious behavior if the person is subjectively willing for that conduct to occur. Such consent can be express or can be inferred from the facts. Actual consent ordinarily is, but need not be communicated to the actor." 66 This provision embraces a "mental state" approach to consent and finds consent even in rare instances in which a person desires to engage in an act but has

66 RESTATEMENT (THIRD) §13(a). 
given no indication to the defendant that he has her permission to act. A quaint scenario, seemingly patterned on a party attended by adolescents, is offered to demonstrate that "actual consent need not be communicated to the actor." 67 The Illustration explains that " $\mathrm{B}$, while attending a party, confides to his best friend that he is very attracted to A and would like very much to kiss her, but he has been afraid to express his feelings to her or to make the first move. Unknown to $\mathrm{B}, \mathrm{A}$ is at the party. On a dare from a friend, she suddenly walks up to B and kisses him, before he has any chance to respond. A is not liable to B." The surprise kiss in the illustration is consensual, according to the Restatement, because B is "willing to permit" what occurred, in this instance equating B's sexual attraction or desire with willingness. We are not told whether someone in B's position might have misgivings about not making the "first move," or being made the object of a dare, presumably because, in the Illustration, B just wants the kiss and has no other desires.

More importantly for our purposes, in the run-of-the-mill cases not involving uncommunicated consent, the Restatement's definition of actual consent turns out to be a very thin concept that need not reflect a party's sexual or romantic desires. The commentary indicates that consent is synonymous with "subjective willingness," defined further as "assent or acquiesce[ence] to the actor's conduct or invasion." ${ }^{68}$ We are told that effective consent can be given reluctantly, as illustrated by an example of an individual who reluctantly agrees to have intercourse with her partner when the partner threatens to break off the relationship. The "willingness" that is the touchstone of actual consent, moreover, need not be given expressly and can be inferred from the plaintiff's conduct as well as her words.

The Reporters are aware that the thin version of actual consent adopted in Section 13 is in tension with affirmative consent. In the commentary to Section 13 , they state that a state court or legislature might in "special circumstances" require "a more robust type of consent," noting that "consent to sexual intercourse might require more than the willingness of both parties to engage in that conduct." 69 The commentary goes on to mention that the criminal law in some states requires proof of affirmative consent and that "[t]his standard might be adopted in tort cases as well."70 The implication here is that a state might want to follow its criminal law on this issue. One can also discern a negative implication in the comment, i. e., that there is no warrant for adopting affirmative

67 Id. at $\S 13$, illus. 4.

68 Id. at $\S 13$, cmt. b.

69 Id. at $\S 13$, cmt. g.

$70 \mathrm{Id}$. 
consent in tort cases involving sexual conduct in the vast majority of states that have not adopted an affirmative consent standard in their criminal law.

In the Reporters' Note to Section 13, the Reporters create additional distance between affirmative consent and the requisites of actual consent under Section 13 by disputing a "famous hypothetical" offered by Steven Schulhofer. ${ }^{71}$ The hypothetical involves an athlete who is "ambivalent about whether to undergo surgery when the surgeon asks for his consent." Schulhofer argues that we would not treat the athlete as consenting to the operation if the surgeon proceeded with administering anesthesia, “despite the athlete's silence or ambiguous attitude" and that it is likewise "unjustifiable to treat silence or an ambiguous attitude in response to a request for sexual intercourse as consent to that conduct.” The Reporters reply that the medical hypothetical can be distinguished from a case involving consent to sexual intercourse because "willingness is often more plausibly inferred from a course of sexual conduct, even absent express words or conduct, than from an ambiguous response to a doctor's question whether one wishes to undergo surgery." 72 In that statement, the Reporters seem to endorse a finding of actual consent, even in the absence of "express words or conduct" signaling such consent, thereby suggesting that silence and ambiguous conduct can legitimately be interpreted as actual consent. They also endorse different or exceptional treatment of sexual conduct cases, as compared to medical consent cases.

\subsection{Apparent consent}

Aside from the definition of actual consent, the Restatement departs from affirmative consent by its endorsement of apparent consent in $\S 16$. That section provides that "an actor is not liable to another if a reasonable person in the position of the actor would believe that the other actually consents to the actor's otherwise tortious intentional conduct."73 Under this definition, apparent consent turns on the defendant's interpretation of the plaintiff's mental state, by first instructing that we view events from a person in the position of the actor/ defendant, and then asking whether that interpretation is reasonable. The commentary indicates that in making determinations of reasonableness, "the customs of the community" are highly relevant, particularly in cases of "silence

71 Id. at § 13, Rptrs. Note, cmt. g, citing Steven Schulhofer, Taking Sexual Autonomy Seriously, 11 LAW \& PHIL. 35 (1992).

72 Id.

$73 I d$. at $\S 16$. 
and inaction." ${ }^{\text {74 }}$ Without mentioning the problem of contested norms and differing perspectives, the commentary contends that it is fair to allow defendants to rely on "reasonable appearances" and that it is fair to require the non-initiating party to register an objection, arguing that "[a] person who objects to the behavior of an actor that most other persons find unobjectionable or desirable often retains the ability to express that objection and thus to deny the application of apparent consent."75

The Restatement's commentary on apparent consent makes it clear that it is the defendant's interpretation of events that matters (provided it is judged to be reasonable) and that it is fair to exclude the perspective of the plaintiff. It is especially noteworthy that the Restatement takes the position that the defendant's reasonable belief need not be based on the words or affirmative conduct of the plaintiff. ${ }^{76}$ According to the Restatement, a defendant is entitled to rely on "customary norms" or other reasonable assumptions in making his assessment about whether plaintiff consented. Further, such a defendant is characterized as acting "without fault" if he proceeds without stopping and asking for permission. Remarkably, there is no discussion in the commentary about whether the basic concept of apparent consent is inconsistent with affirmative consent or whether states might choose to abandon apparent consent in favor of affirmative consent in sexual conduct cases.

The commentary on apparent consent does, however, directly address sexual conduct cases in comment (f), in connection with a discussion about evolving norms. It first notes that the Restatement's section on battery (\$3) declares that "any nonconsensual contact with a sexual purpose" offends a reasonable sense of personal dignity and acknowledges that whether sexual conduct is nonconsensual is "thus a critically important question in determining whether the actor has committed an offensive battery."77 Rather than grappling with contested norms and the differing perspectives of men and women, however, the Restatement relies on evolution in the meaning of reasonableness to reach the right result, stating that "[a]s social norms about acceptable sexual behavior evolve, the meaning of 'reasonable' belief that the plaintiff was willing for the sexual contact to occur must adapt to that evolution." "78 The commentary then proceeds to endorse a "no means no" approach to sexual conduct, stating that

74 Id. at $\S 16$, cmt. b.

75 Id.

76 Id. at $\S 16$, cmt. c.

$77 \mathrm{Id}$. at $\S 16$, cmt f.

78 Id. 
"if plaintiff expresses his or her objection to any sexual act, the actor cannot rely upon plaintiff's apparent consent."79

The commentary on apparent consent concludes with a confusing Illustration that directly confronts the problem of differing perspectives in an acquaintance rape scenario. ${ }^{80}$ We are asked to imagine a situation where $\mathrm{E}$ and $\mathrm{F}$ are "on a first date." After kissing, "E and F disrobe" and "E asks F if $F$ is willing to engage in sexual intercourse." We are told that "[a]lthough inwardly objecting, F says nothing and does not express unwillingness by words or conduct.” Presumably in such a case the doctrine of apparent consent would permit E to penetrate the unwilling $\mathrm{F}$ if $\mathrm{E}$ reasonably believes that $\mathrm{F}$ has consented. The Illustration concludes by stating that “[w]hether $\mathrm{E}$ is justified in relying on F's apparent consent depends on the jurisdiction's norms with respect to consent to sexual intercourse. If those norms provide that a reasonable person in E's position should not treat F's conduct as consensual unless F has affirmatively expressed willingness, then E many not rely on apparent consent, and E is subject to liability to F for battery."

The Illustration thus appears to leave room for a jurisdiction to smuggle a version of affirmative consent into apparent consent, provided affirmative consent is embodied in the "norms" of that particular jurisdiction. As I read the Illustration, apparent consent is negated because in such a jurisdiction it would no longer be reasonable for a defendant to interpret a plaintiff's silence and passivity as consent. Although the Illustration does not specify where a court should go to find the source of the jurisdiction's norms, the Reporters' Note suggests that the norms referred to in the Illustration are norms gleaned from the state's criminal law. ${ }^{81}$ If my reading is correct, then it is important to recognize that the Illustration also suggests that in the vast majority of states that have not adopted affirmative consent in their criminal law, E presumably may reasonably interpret F's silence and passivity as consent. In this respect, the Illustration of apparent consent is consistent with the commentary on actual consent in that each defers to a state's criminal law to determine the standard for consent in tort cases.

\subsection{Burden of proof}

Perhaps the most noticeable aspect of the new Restatement's provisions on consent is its assignment of the burden of proof. The Restatement attempts to

79 Id.

$80 \mathrm{Id}$. at $\S 16$, illus. 11.

81 Id. at $\S 16$, Rptrs Note, cmt. f. 
clear up confusion in the case law by assigning the burden to plaintiffs to prove their absence of consent with respect to actual consent. ${ }^{82}$ The commentary explains that because the plaintiff "ordinarily has greater access to the facts relevant to actual consent," it is "both fair and efficient to require plaintiff to demonstrate absence of consent as part of his or her prima facie case." ${ }^{\text {" } 3}$ It downplays the significance of placing the burden of proving a negative on the plaintiff, indicating that if plaintiffs must testify on the issue of consent in contested cases, "then it usually will not matter which party has the burden of production, and it frequently will not matter which has the burden of persuasion." 84

The commentary considers, and seemingly rejects, shifting the burden of proof to the defendant in cases involving sexual conduct. The commentary notes that some criminal-law rules and student disciplinary standards require affirmative consent and that "[o]n one understanding, affirmative consent shifts the burden of persuasion to the actor initiating the intercourse to show that his or her partner actually consented to this level of intimacy." 85 However, later in the Reporters' Note, they remark that if states wish to adopt affirmative consent, they may do so without shifting the burden of consent to the defendant. In their view, "even if plaintiff is required to prove the absence of such [affirmative] consent, discharging that burden only requires plaintiff to prove that he or she did not express affirmative permission by words or conduct. If plaintiff shows that the circumstances were ambiguous, with no such expression of permission, plaintiff succeeds in showing the absence of "consent," so defined." 86 Through this ingenious interpretation, the substantive obligation to assure that one's sexual partner has given affirmative consent is severed from the assignment of the burden of proof, assigning the proof burden not to the party who initiated the sexual conduct but to the target of the conduct.

To be fair, the commentary displays some concern about assigning the burden to the plaintiff to prove lack of actual consent in sexual conduct cases. It acknowledges that assigning the burden to the defendant might have the advantage of encouraging those who initiate sexual conduct "to be quite certain" that the other party genuinely consents and notes that it would "ease the burden

82 The language specifying that the burden of proof is on the plaintiff is found in the definitions of each of the intentional torts. See §1, cmt. f (battery); §4, cmt. d (purposeful infliction of bodily harm); $\S 5$, cmt. j (assault); $§ 7$, comment $\mathrm{k}$ (false imprisonment).

83 Id. at $\S 12$, cmt. d.

$84 I d$.

$85 \mathrm{Id}$. at $\S 12$, cmt. d.

86 Id. at $\S 12$, Rptrs. Note, cmt. d. 
on plaintiffs to prove sexual battery where physical evidence of violation is difficult or impossible to produce." ${ }^{87}$ Perhaps most significantly, the commentary recognizes the social impact of assigning the burden of proof to the plaintiff, rather than to the defendant, in light of the "overwhelming evidence of the frequency of sexual assault and the relative infrequency of successful tort recovery." 88 Nevertheless, because the commentary finds no support in the case law for assigning the burden to the defendant, these concerns do not carry the day.

With respect to assignment of the burden of proof in cases of apparent consent, the Restatement has little to offer and it says nothing about affirmative consent. For "simplicity" sake, the Reporters suggest, the burden of proof should be assigned to the plaintiff, to parallel the assignment in actual consent cases. ${ }^{89}$ On the other hand, they acknowledge that a defendant will "normally have significantly greater access to the relevant evidence than will the plaintiff" and they ultimately decide to leave the question to "judicial development." 90 This means that plaintiffs in sexual conduct cases may be saddled with the burden of disproving that the defendant reasonably believed that she had consented, i. e., that a plaintiff will have to prove that defendant's interpretation of events was unreasonable, all the while taking the defendant's perception of events as controlling.

\section{The restatement's incompatibility with affirmative consent}

As the foregoing description suggests, each of the three aspects of consent discussed above - the substantive definitions of actual and apparent consent and the placement of the burden of proof - are in tension with affirmative consent. Despite the efforts of the Reporters to carve out room for individual states to adopt affirmative consent in sexual conduct cases, I fear that the structure of the new Restatement's provisions are fundamentally incompatible with the basic concept of affirmative consent and could serve to deter states from adopting affirmative consent in sexual battery cases. To put it most succinctly, the conception of consent embedded in the Restatement's definition of actual consent is too thin to capture the affirmative duty of a sexual partner to secure permission from the other that is a hallmark of affirmative

87 Id. at $\S 12$, cmt. d.

88 Id.

89 Id.

90 Id. 
consent. The Restatement's definition of apparent consent fundamentally departs from affirmative consent's commitment to recognizing the perspective of the victim and allows too much leeway for defendants to interpret plaintiff's silence or ambiguous conduct as consent. And placing the burden of proof on the plaintiff to prove her lack of consent in actual consent cases (and possibly even apparent consent cases) has the tendency to revive the traditional criminal law approach that often presumed a victim's consent in sexual assault cases and required proof of her active resistance to counteract the presumption.

\subsection{Actual consent}

To elaborate somewhat, the thin concept of actual consent in the Restatement allows a finding of consent when the plaintiff merely acquiesces in or reluctantly submits to a defendant's aggressive conduct. Although the Restatement's notion of consent purportedly turns on the plaintiff's mental state, the mental state required to declare sexual conduct "consensual" is a far cry from requiring evidence of a plaintiff's actual desire to have sex, in the sense that one could say that the plaintiff would have initiated the contact had the defendant not done so first. This thin concept of consent may be satisfied in cases where plaintiff responds passively but cannot realistically be said to have agreed to defendant's behavior, for example, in cases in which a plaintiff is worn down by defendant's persistent overtures and merely gives up and gives in. Finding consent in such a case hardly serves to reinforce the sexual autonomy or self-determination of plaintiffs and mainly mimics a "sexual conquest" model of sexuality, ${ }^{91}$ rewarding the more powerful and aggressive party. Moreover, this thin version of consent can arise from a plaintiff's conduct as well as her words and, as Schulhofer's athlete and the surgeon hypothetical teaches us, ${ }^{92}$ permits a finding of consent in cases of silence and ambiguous conduct. Presuming consent from silence or in ambiguous circumstances goes sharply against the grain of affirmative consent which seeks to counteract the traditional criminal law's penchant for presuming consent in such circumstances. Finally, because the Restatement allows even unexpressed, uncommunicated desire to qualify as consent, it is at odds with a performative conception of affirmative consent that requires a plaintiff to give her permission before a defendant is entitled

91 See supra at note 34.

92 See supra at note 71. 
to act, even if she is sexually attracted to the defendant or otherwise might be said to have desired his conduct.

\subsection{Apparent consent}

Even more pointedly, the Restatement's endorsement of apparent consent in sexual conduct cases cannot be squared with any version of affirmative consent. To establish apparent consent, all that must be proven is that "a reasonable person in the position of the actor" would have believed that plaintiff consented. The Restatement opts for an interpretation of apparent consent that allows the factfinders to find apparent consent even when defendant's belief does not stem from the plaintiff's own words or actions. This definition leaves the door wide open for a defendant to interpret a plaintiff's silence or passivity as consent, allowing rape myths and tire-worn, insidious cultural beliefs about women's supposed desires and the meaning of women's responses to fill in the silence.

The Restatement's definition of apparent consent also explicitly endorses the perpetrator's or defendant's perspective. We are instructed to evaluate the situation from the perspective of a reasonable person in the position of the actor, namely, to ask how a reasonable defendant would interpret events, excluding the plaintiff's perspective in the process. Particularly when it comes to interpreting sexual behavior - where there are frequently differing perspectives and misunderstandings - the doctrine of apparent consent seems to come down on the side of the defendant. In doing so, the law affords greater weight to the potential cost of holding an "honest" (but oblivious or mistaken) defendant civilly liable than it does the cost of denying recovery to a plaintiff who has been sexually violated. This balancing of interests reverses the usual priority of interests by upsetting the principle that a person's right or desire to enter into an intimate relationship is outweighed by the right of a person to deny or refuse an intimate relationship. Although the interest in promoting consensual sexual relationships may be a legitimate one, it should be subordinated to the risk of legitimating or facilitating nonconsensual encounters. Finally, when sexual encounters are labeled "consensual" due to the operation of the apparent consent doctrine, it tends to normalize non-consensual sex, at least if we measure consent in part by the target's perspective and desires.

With respect to apparent consent, I do not believe that social norms will simply "evolve" 93 and that someday (or in some jurisdictions), a consensus will develop that makes it "unreasonable" for a defendant to fail to secure the

93 RESTATEMENT, § 16, cmt. f. 
affirmative consent of a sexual partner. Instead, the meaning of consent is likely to remain contested and tort law will be called upon to make a choice between competing norms and perspectives. In my view, affirmative consent cannot easily be smuggled into the doctrine of apparent consent through evolving concepts of "reasonableness."

\subsection{Burden of proof}

Aside from the substantive definitions of actual and apparent consent, the Restatement's placement of the burden of proof in consent cases is at odds with affirmative consent. Placing the burden of proof on the plaintiff to prove her lack of actual consent is inconsistent with a core feature of affirmative consent, namely, that it is the duty of the initiator of sexual conduct to make sure that the plaintiff consents to what would otherwise be tortious conduct. It is awkward to place the burden of proof on a party owed an obligation, rather than on an actor who is under an obligation. Once we accept that affirmative consent imposes an obligation, we can see also that the defendant is in the best position to offer proof that he discharged his duty, although plaintiff, of course, may contest defendant's evidence. In such cases, characterizing defendant's burden as establishing an affirmative defense seems appropriate, given that a presumptive invasion of plaintiff's interests has occurred. Placing the burden of proof on the plaintiff, on the other hand, seems to presume consent and is reminiscent of consent presumptions in traditional criminal law.

In sexual conduct cases, moreover, I disagree with the proposition stated in the commentary that it "frequently will not matter which party has the burden of persuasion." 94 Indeed, in acquaintance rape and other sexual misconduct cases, parties often give conflicting testimony ("he said, she said") and the outcome may well depend upon the burden of proof. If the plaintiff is saddled with the burden of proving that she did not consent, it is a smaller step for a juror to imagine that because the plaintiff did not offer resistance (either physical or verbal), the defendant should prevail. Although assignment of the burden of proof does not technically reinstate the resistance requirement, I fear that, absent evidence of resistance, a plaintiff will find it difficult to convince the factfinder that she did not consent, even if a jurisdiction were to adopt a version of affirmative consent.

Finally, imposing a burden of proof on the plaintiff in apparent consent cases seems hostile to any notion of affirmative consent. If the plaintiff must

94 Restatement, § 12, cmt. d. 
prove that the defendant was unreasonable in believing that she consented from the perspective of a person in the position of the defendant - the plaintiff is not likely to shoulder that burden simply by claiming that she was silent or passive or otherwise did not affirmatively consent. The whole point of apparent consent seems aimed at giving controlling weight to a defendant's interpretation of a plaintiff's silence or ambiguous conduct, making it extremely difficult for plaintiff to prove otherwise. Because the concepts of apparent consent and affirmative consent are antithetical, placing the burden of proof on the plaintiff to prove lack of consent in apparent consent cases only exacerbates the tension.

\section{Finding room for affirmative consent in the restatement}

If affirmative consent is indeed incompatible with the draft consent provisions of the Restatement, there remains the question of whether the Restatement could embrace affirmative consent, consistent with the Restatement's mission to "reflect the law as it presently stands or might appropriately be stated by a court." "95 As a special type of law reform project, the Restatement must generally respect controlling case law and majority views. However, where there is little precedent directly on point, the Restatement is free to look to "policy, principle, and coherence with the broader body of law" and determine what principle "fits best with the broader body of law."96

With respect to consent in sexual conduct cases, there appears to be very little case law at all and thus no real constraints on fashioning an appropriate rule that fits best with the broader body of law. Compared to other Restatement projects, such as the Restatement on Liability for Physical and Emotional Harm, there are far fewer intentional tort cases to analyze, as reflected in the discussion of cases in the Reporters' Notes, which are largely devoted to medical consent cases. Of course, one could strive to be consistent and apply the same rules in medical consent and sexual conduct cases. Such a superficial consistency in treatment, however, may be misleading, given that patients in the medical consent cases are also afforded very broad protection by the negligence doctrine of informed consent. Importantly, there is no parallel negligence doctrine of informed consent protecting plaintiffs in sexual conduct

95 RESTATEMENT (excerpts of the Revised Style Manual approved by the ALI Council in January 2015), at p. $x-x i$.

96 Id. 
cases, unless, of course, we regard affirmative consent as a kind of informed consent. My point here is that attempting to fashion general rules on consent to govern all intentional tort cases is very tricky if based only on a limited set of cases (i. e., medical cases, sexual conduct cases and athletic injuries) that each has distinctive features.

With respect to actual consent, the Reporters' Notes indicate that there are no cases on whether consent must be communicated ${ }^{97}$ and they cite to no tort cases for the main proposition that a party's mere willingness or acquiescence suffices to establish actual consent in sexual conduct cases in which the plaintiff is silent or passive.

With respect to apparent consent, the only sexual conduct case cited is Reavis v. Slominski, ${ }^{98}$ a confusing 1996 decision by a badly split Nebraska Supreme Court. Reavis is essentially a sexual harassment case in which a plaintiff alleged that she was sexually assaulted by her employer. The case produced five separate opinions and much of the discussion centered on whether plaintiff's fear of losing her job was sufficient duress to render her consent ineffective and whether plaintiff's history of sexual abuse as a child affected her capacity to consent. It is true that the trial judge in that case instructed the jury on actual and apparent consent, tracking the Restatement's definitions of consent, and neither the supreme court, nor the parties, objected to the definitions. However, the court ultimately reversed a jury verdict for the plaintiff, ruling that a new trial was necessary because the jury instructions on whether plaintiff's consent was effective were erroneous. In my view, Reavis does not qualify as controlling precedent. It is an isolated case that did not turn on the proper definition of actual and apparent consent. It thus leaves plenty of room for adoption of a different definition of consent that fits better with the "broader body of law."

Given the lack of controlling precedent, the key question becomes which body of law the Restatement should turn to as a model for tort law. Judging from the multiple references to the new draft provisions of the Model Penal Code in the Restatement commentary and the Reporters' Notes, the answer seems to be that the Restatement is following the path of the criminal law, rather than turning to civil rights law and Title IX. With respect to the law of consent, that choice is critical. As we have seen, there is a move to embrace affirmative consent in civil rights law, while the criminal law has been resistant to such a move and is only now beginning to adopt a "no means no" approach to consent.

I realize that relying on the criminal law in the context of intentional torts is a familiar move, for the simple reason that many intentional torts are also crimes

97 RESTATEMENT, §13, cmt. e.

98250 Neb. 711 (1996), cited in Restatement, § 16, Rptrs. Note, cmt. f. 
and, in the broader culture, criminal law dominates popular discourse when it comes to assessing anti-social behavior. Additionally, because negligencerather than intentional torts - has taken center stage in the creation of tort theories and in torts scholarship, there has not been much theorizing about important intentional tort topics, such as the meaning of consent. It is understandable that one would look to developments in criminal law where there is more writing about consent and sexual assault and the topic has been vigorously debated during the deliberations of the Model Penal Code.

However, as I hope my discussion makes clear, I believe it would be a mistake to model the Restatement provisions on the criminal law definition of consent. The criminal law has been woefully under-protective of the interests of sexual assault victims and still contains traces of the "force" and "resistance" requirements that historically were intertwined with the criminal law concept of consent. The criminal law's ambivalence about whether non-consensual sexual intercourse (without force) ought to be considered a crime has meant that it has done little to cut down on high rates of acquaintance rape or to curb "rape prone" sub-cultures. If tort law were to follow its lead, we could expect the same result.

Most significantly, a good deal of the reluctance to embrace affirmative consent under the criminal law has little or no bearing on tort law. Many critics of affirmative consent are motivated, at least in part, to resist incorporating victim-oriented approaches into the criminal law because of what they regard as unconscionably high rates of incarceration in the U.S. ${ }^{99}$ Such anti-carceral critics push against what they see as a trend toward over-criminalization and overly punitive responses to pervasive forms of behavior.

Providing a remedy in tort, of course, does not contribute to mass incarceration and does not trigger sexual offender registry laws or other collateral consequences. Moreover, the procedural restrictions associated with criminal law are not present in civil litigation: there are no tort principles requiring a presumption of innocence, proof beyond a reasonable doubt, or a privileging of the rights of the defendant over the interests of the victim to assure that a defendant's liberty is not taken away without due process. Additionally, deep concerns about the highly disproportionate effects of criminal law on racial minorities and the poor are not readily transferable to this aspect of tort law and civil litigation. There is no question that criminal prosecutions pose a particular burden on poor, minority defendants who are more likely than whites and more affluent defendants to be con-

99 See Aya Gruber, Rape, Feminism, and the War on Crime, 84 WASH. L. REV. 581, 651-657 (2009) (urging feminists to disengage from rape reforms that strengthen the penal state). 
victed and incarcerated. ${ }^{100}$ However, it is not the case that poor, minority defendants are more likely to be sued in tort, particularly when one considers that plaintiffs and their attorneys generally prefer to sue defendants who are insured or have assets to satisfy tort judgments. Although racial and other forms of invidious discrimination certainly do affect outcomes in individual tort cases, ${ }^{101}$ adopting a victim-oriented rule such as affirmative consent in intentional tort cases involving sexual conduct does not risk producing systemic racial, ethnic or class bias against defendants.

In my judgment, tort law should look to developments in civil rights law as a model for intentional tort sexual conduct cases. In many respects, doctrine under Title VII and Title IX has developed against the grain of criminal law. It has attempted to provide a remedy for victims of sexual misconduct in situations where they was no punishment under the criminal law, reflecting a judgment that the criminal law has historically been skewed against the interests of victims, particularly women. Not surprisingly, when the interests of victims are prioritized, criminal law definitions of consent must either be significantly changed or discarded: Title VII changed our conception of what constitutes impermissible coercion that renders consent ineffective; Title IX has altered our understanding of the basic ingredients and nature of consent, particularly in cases of acquaintance rape.

The migration of civil rights principles into tort law is not a new phenomenon. In adjudicating claims for intentional infliction of emotional distress, for example, courts have permitted recovery in racial and sexual harassment cases and have borrowed civil right concepts (e. g., hostile work environment) for that purpose. ${ }^{102}$ Moreover, in recent years, the U.S. Supreme Court has repeatedly interpreted Title VII "against the background of general tort law," ${ }^{103}$ going so far as to regard Title VII as "a federal tort."104 By forging this connection between civil rights and civil wrongs, the courts have eased the way for a similar migration to occur in sexual battery claims.

100 See Michelle Alexander, The New Jim Crow: Mass InCarceration in the Age of COLORBLINDNESS 9 (2010) (one in three young African American men are under control of criminal justice system); Ian Haney Lopez, Post-Racial Racism: Racial Stratification and Mass Incarceration in the Age of Obama, 98 CAL. L. REV. 1023 (2010).

101 See Martha Chamallas \& Jennifer B. Wriggins, The Measure of Injury: RaCE, Gender \& TORT LAW 184-188 (2010) (discussing six “pathways" by which race and gender influence U. S. tort law).

102 See Martha Chamallas, Discrimination and Outrage: The Migration from Civil Rights to Tort Law, 48 WM. \& MARY L. REV. 2115, 2118-2119 (2007).

103 Staub v. Proctor Hosp., 562 U.S. 411, 417 (2011).

104 Id. On the migration process, see generally, Martha Chamallas \& Sandra F. Sperino, Torts and Civil Rights Law: Migration and Conflict: Symposium Introduction, 75 Оніо ST. L. J. 1021 (2014). 
To date, tort law has been underutilized in addressing sexual violence, at least with respect to claims against individual perpetrators. ${ }^{105}$ As Ellen Bublick's research demonstrates, ${ }^{106}$ the vast majority of tort claims for sexual assault are brought as "third-party" negligence claims against institutional defendants, holding landlords, schools, and commercial enterprises liable for failing to take reasonable precautions to prevent assaults. It also appears that a large number of these "third-party" negligence claims involve rapes and assaults by strangers, rather than acquaintance rapes. In comparison, few intentional tort suits are brought directly against the assailant. As the Reporters of the Restatement have recognized, there has been a paucity of successful tort recoveries against assailants, given the "overwhelming evidence of the frequency of sexual assault."107

The underutilization of intentional tort claims for sexual misconduct comes with a cost. Recently, Sara Swan has reminded us of the importance of having "complainant-driven processes" in the sexual assault context. ${ }^{108}$ She stresses that "by enabling a person to bring a claim or not, at his or her discretion, tort law is understood as empowering victims." In contrast to criminal law, tort law has the potential to reinforce the agency of a victim-plaintiff and to give her an opportunity to assert her "inherent dignity." "109 Particularly in cases of sexual misconduct, where victims' perspectives and interests have historically been suppressed or minimized, allowing the victim to drive the process has great value.

On a more practical level, tort law offers distinct advantages in litigating claims for sexual misconduct. Because tort law remedies are individualized, with damages set at the amount of harm suffered by the individual plaintiff, there is no need to make difficult decisions about the relative seriousness of particular types of conduct. Thus, in tort law, for example, there is no need to classify nonforcible, non-consensual intercourse as either a misdemeanor or a felony, a contentious debate within criminal law. Similarly, in sexual misconduct cases involving harmful or offensive touchings other than sexual intercourse, the relative seriousness of the particular injury can be measured by the amount of actual damages proven, just as in other tort cases. Overall, the structure and process of tort litigation makes it a valuable tool in combatting the high

105 See Tom Lininger, Is it Wrong to Sue for Rape? 57 DukE L. J. 1557, 1568 (2008).

106 Ellen M. Bublick, Tort Suits Filed by Rape and Sexual Assault Victims in Civil Courts: Lessons for Courts, Classrooms and Constituencies, 59 SMU L. REV. 55, 58-61 (2006).

107 RESTATEMENT (THIRD), § 12, cmt. d.

108 Sarah L. Swan, Between Title IX and the Criminal Law: Bringing Tort Law to the Campus Sexual Assault Debate, 64 KAN. L.REV. 961, 970 (2016).

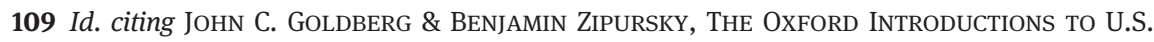
LAW: TORTS 6 (2010). 
incidence of sexual assault. Although tort law is likely never to become the primary vehicle for addressing sexual violence and assault, its role as a supplementary remedy could be enhanced by the aligning tort law with civil rights principles and adopting a rule of affirmative consent.

Finally, the Title IX models of affirmative consent could readily be adapted to fashion a rule governing consent in intentional tort cases of sexual misconduct. Both the California and New York affirmative consent statutes, described earlier, ${ }^{110}$ contain appropriate language to borrow for such a purpose, providing that affirmative consent requires a "conscious," "voluntary," "decision" or "agreement" to engage in sexual activity, creating a "mutual" obligation to ensure that the actor has secured permission from the other party. Perhaps most importantly, each specifies that "silence," "lack of protest" or "lack of resistance" does not "mean" or "demonstrate" consent. Because affirmative consent is fundamentally incompatible with the doctrine of apparent consent, if the Restatement were to adopt affirmative consent, it must also clarify that apparent consent may not be applied in such a context. Finally, if affirmative consent were the governing standard, it would be clear that the burden of proving such consent should rest with the defendant, consistent with his or her obligation to secure permission before invading the interests of the plaintiff.

As a second-best option, I would prefer that the Restatement expressly take no position as to whether its "general" consent provisions defining actual consent, apparent consent and burden of proof apply to sexual conduct cases. Such neutrality would send a clear signal that states are free to treat consent in sexual conduct cases differently from other intentional tort claims and would clear the way for adoption of affirmative consent. Although the current draft mentions that a jurisdiction might adopt a rule of affirmative consent - particularly if affirmative consent is used in that state's criminal law - it does not make clear that apparent consent is incompatible with affirmative consent, nor does it recognize that placing the burden of proof on the plaintiff to prove lack of consent in such a jurisdiction makes little sense.

The current draft of the Restatement sidesteps the important debate on affirmative consent and sends mixed messages. Although affirmative consent is not ruled out completely, the draft underappreciates the significant role tort law could play if it did not simply track developments in criminal law. Given the current dissatisfaction with criminal law solutions to pressing social problems, the Restatement should not miss this opportunity to help fashion a distinctive tort law of consent.

110 See supra at nn. 19, 64. 